\title{
Nanobodies: Diagnostic and Therapeutic Antibody Fragments
}

\section{Nanokorlar: Tanı ve Tedaviye Yönelik Antikor Fragmanları}

\author{
Nihal Karakaş ${ }^{1}$, İrem Öztürk ${ }^{1}$, Serkut Tosyalı ${ }^{1}$, Sadık Bay ${ }^{1}$ \\ İstanbul Medipol Üniversitesi, Tıp Fakültesi, Tıbbi Biyoloji Anabilim Dalı ve Rejeneratif ve Restoratif Tıp \\ Araştırmaları Merkezi (REMER), İstanbul, Türkiye
}

\section{ÖZET}

Nanokorlar, bilinen en küçük ve fonksiyonel antikor fragmanlarıdır. Yapısında sadece iki ağır zincir bulunduran antikorların (heavy chain only antibodies; HcAb) antijen bağlama bölgesi, "nanokor" (nanobody) olarak adlandırılmıştır. Böylelikle bütün bir antikor molekülü kadar fonksiyonel olan ve sadece ağır zincirden oluşan (variable domain of the heavy chain of $\mathrm{HcAb}$; VHH) en küçük antikor fragmanı tanımlanmıştır. Nanokorlar, küçük boyutları sayesinde antikorların ulaşamadığı bölgelere dahi bağlanabilmektedir. Bunun yanında immün tepkimelere yol açmamaları ve görüntülemede diğer antikorlara nazaran daha iyi sonuç vermeleri sebebiyle son y1llarda kanser, enfeksiyon, enflamasyon ve nörodejeneratif hastalıklar başta olmak üzere pek çok hastalığa yönelik tanı ve tedavi amaçlı araştırmalarda kullanılmaya başlanmıştır. Vücut sıvılarında bulunmasının dışında prokaryotik ve ökaryotik canlılarda da kolayca üretilebilmesi ile nanokorlar, rekombinant proteinler olarak da elde edilebilmektedir. $\mathrm{Bu}$ sayede, nanokorlara entegre edilerek terapötik moleküller geliştirilmektedir ve bu çalışmalarla birlikte nanokorlar, hedefe yönelik tedavi yaklaşımları için yeni perspektifler sunmaktadır. Ayrıca nanokorlara özgün görüntüleme ajanları bağlanarak, tanı amaçlı moleküller de oluşturulmaktadır. Nanokorların biyosensör olarak kullanılmasına ilişkin sürdürülen çalışmalar ise in vivo görüntüleme için yeni araçlar geliştirilmesine olanak sağlayacaktır.

Anahtar kelimeler: Nanokor, antikor, tanı ajanları, terapötikler, moleküler görüntüleme

\begin{abstract}
Nanobodies are the smallest and functional antibody fragments ever known. Antigen-binding region of antibodies composed of two heavy chains only (heavy chain only antibodies; HcAb) is termed as "nanobody". Thus, the smallest antibody fragment that is as functional as a whole antibody and comprises of only heavy chains has been identified. Recently, nanobodies have been used in the diagnosis and treatment of numerous diseases including especially cancer, infection, inflammation, and neurodegenerative diseases since they are the smallest functional antibody fragments, do not lead immunological reactions, have better imaging capacities than other antibodies. Beside residing in body fluids, nanobodies can be engineered as recombinant proteins since they can be easily produced in both prokaryotic and eukaryotic organisms. Furthermore, several therapeutic molecules integrated to nanobodies have been developed and in the light of these studies, nanobodies provide new perspectives to targeted therapy approaches. In addition to that, nanobodies can be served as diagnostic molecules upon modification with imaging agents. Ongoing research about the use of nanobodies in biosensor development is another promising area that allow the development of new tools for in vivo imaging.
\end{abstract}

Keywords: Nanobody, antibody, diagnostic agents, therapeutics, molecular imaging

\section{GíRiş}

Antikorlar temel olarak, yapılarında iki ağır ve iki hafif zincir bulunduran proteinlerdir. Özgün olarak antijen bağlama yetenekleri sayesinde antikorlar, hastalıkların önceden teşhis ve tedavisine imkan sağlayabilmektedir.
Moleküler büyüklükleri ve immün tepkimelere sebep olmaları gibi özellikleri ise klinik olarak kullanımlarını sinırlandırmaktadır. Ayrica yar1 ömürlerinin uzun olmas1 moleküler görüntülemede fazla miktarda arka plan oluşumuna sebep olup; sağlıklı sonuçlara ulaşılmasını engellemektedir $[1,2]$. Bu gibi 
sebepler, daha küçük yapıda ve fonksiyonel moleküllere olan ihtiyacın artmasına sebep olmuştur.

1990'ların başında Hamers-Casterman ve ark. tarafindan Camelidae ailesinde antikorların bilinen yapısı dışında farklı bir antikor çeşidi daha bulunmuştur. Camelidae ailesinde keşfedilen antikorları özel kılan durum ise hafif zincirlerinin bulunmamasidır. $\mathrm{Bu}$ yönleriyle keşfedilen yeni antikorlar, "sadece ağır zincirli antikor; heavy chain only antibodies (HcAb)" olarak adlandırılmıştır. Ağır zincirden oluşan bu antikorların, antijene bağlanabilen k1smina ise "nanokor" (nanobody, VHH) ad1 verilmiştir. Antikorlardan çok daha küçük olmasına rağmen bütün bir antikor molekülü kadar fonksiyonel olan ve antikorların ulaşamadığ iç bölgelere bağlanabilen nanokorlar, sağladıkları avantajlar ile kanser, enfeksiyon, enflamasyon ve nörodejenerasyon gibi birçok hastalığa yönelik tanı ve tedavi ajanları geliştirilmesi çalışmalarına kaynaklık etmektedir [3] (Tablo-1).

\section{Nanokorların Yapısı ve Antikorlardan Farkı}

Antikorlar, iki ağır ve iki hafif zincir olmak üzere dört polipeptit zincirinin disülfat bağlarıyla bir arada tutulduğu "Y" şeklinde büyük proteinlerdir. Her amino asit zincirinin sabit ve değişken olmak üzere iki kısmı vardır ve değişken kısım aynı zamanda "antijen bağlama bölgesi" olarak da adlandırılır. Camelidae ailesinde keşfedilen farklı bir immünoglobülin çeşidinde ise antikorların aksine hafif zincirlere rastlanmamıştır ve bu antikor "sadece ağır zincirli antikor (only heavy chain antibody, $\mathrm{HcAb}$ )" olarak tanımlanmıştır. Keşfedilen bu antikorlar, iki sabit bölge $\left(\mathrm{CH}_{2}\right.$ ve $\left.\mathrm{CH}_{3}\right)$, bir kesişme bölgesi ve sadece ağır zincirden oluşan değişken bölgeden (VHH; antijen bağlama bölgesi) oluşmaktadır. Antikorların yapısındaki antijen bağlama özelliği olan bu bölgeye "nanokor (nanobody; VHH)" ismi verilmiştir [3]. Oval şekilleri, nanokorlara, dış bükey bir bağlanma bölgesi oluşturmakta ve bu sayede antikorların ulaşamadığı reseptör boşluklarına ya da bağlanma bölgelerine ulaşmalarını sağlamaktadır (Şekil-1). daha avantajlı hale getiren en önemli özellikleri, $15 \mathrm{kDa}$ 'luk boyutları sayesinde antikorların ulaşamadığ 1 bölgelere ulaşabilmeleri ve dokuya çok daha iyi nüfuz edebilmeleridir [4-8]. Ayrıca yüksek sıcaklık, ortamda proteaz varlığ 1 , düşük $\mathrm{pH}$ ve yüksek basınç gibi zorlu koşullarda yapılarını korumaları onları benzersiz yapmaktadır [9$13]$.

Tablo 1: Tanı ve Tedaviye Yönelik Geliştirilen

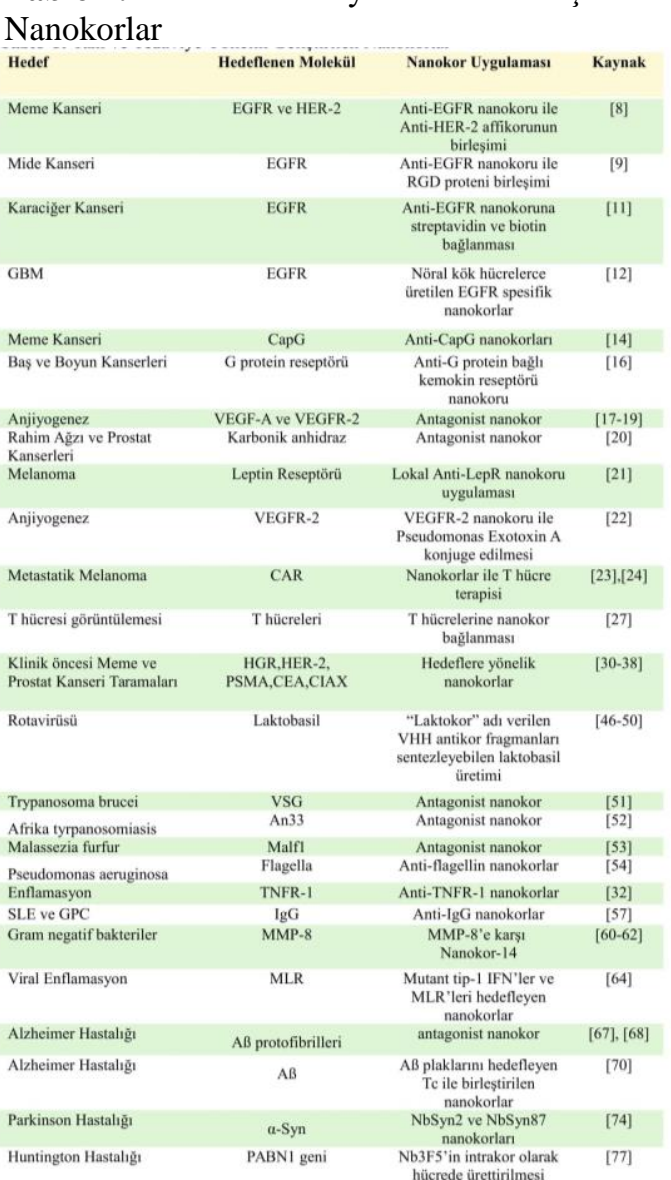

Buna karşı1ık yarı ömürleri çok kısa oluşu görüntülemede ișe yarasa da kronik hastalıklarda tedavi amaçlı nanokor kullanımında dezavantaj oluşturmaktadır. Bu durumu ortadan kaldırmak için nanokorlar, antikorların sabit kısımlarına, albümin gibi serum proteinlerine veya immünoglobülin $\mathrm{G}$ (IgG)'ye bağlanabilirler [14-16]. Albümin proteini enflamasyon bölgelerinde $\operatorname{arttığ~} \breve{i c ̧ i n}$ enflamatuar hastalıklara karşı albümine bağlı nanokor kullanımı ek avantaj sağlayabilmektedir.

Dolay1sıyla nanokorları, antikorlara k1yasla 
Bütün bunlara ek olarak nanokorlar, bakterilerde ve mantarlarda kolayca üretilebilen moleküller oldukları için antikorlara göre çok daha uygun maliyetlidir [17]. Ayrica probiyotik bakterilerde üretilen nanokorlar patojenik enterik bakterilere ulaşmada etkili olabilir. Tek bir genle üretildiklerinden kolaylıkla başka moleküllerle birlikte sentezlenebilirler.

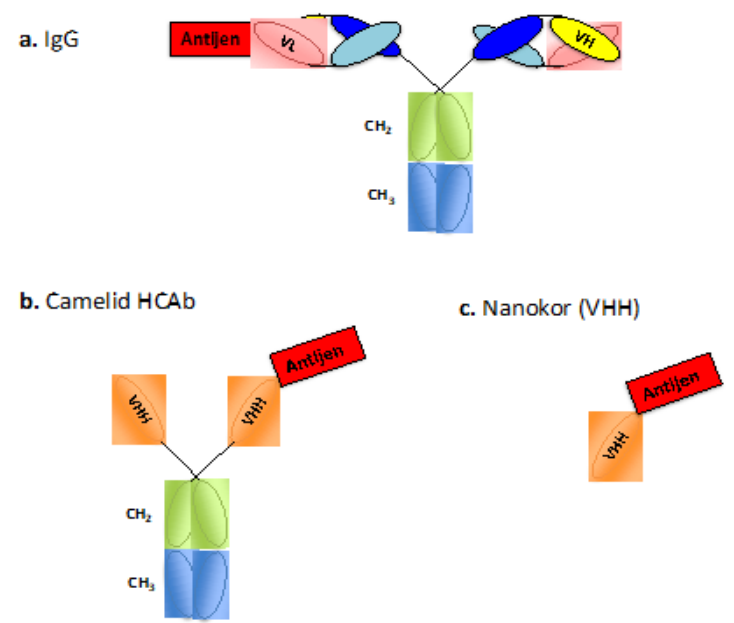

Şekil 1. Antikor fragmanlarının moleküler yapısı. a) İmmünglobülin ( $\operatorname{IgG})$, b) Sadece ağır zincirli antikor (HCAb), c) Nanokor ( $\mathrm{VHH})$.

Hücre içinde sentezlenip kullanılabilen nanokorlara intrakor (intrabody) ad1 verilmiştir ve bu intrakorlar normalde ulaş1lamayan hücre içi proteinleri de hedef alabilmektedir [18]. Nanokorların yapısında bulunan disulfat bağları hücre içinde oluşamasa da intrakorlar, antijene bağlanma kapasitesine sahiptir. Örneğin; kromokorlar (chromobodies) hücre içi proteinlere tutunan ve genetik olarak floresan proteinlere bağlı özel üretilmiş intrakorlardır [19-21]. Bu sayede hücre içi gerçek zamanlı görüntülemeyle hücre döngüsünün ve hücre içi proteinlerinin takibinde kullanılabilirler.

\section{Tanı ve Tedaviye Yönelik Nanokorların Geliștirilmesi $a$. Kanser \\ Tedavi amaçlı yaklaşımlar}

Kanser tedavilerinde, her geçen gün yeni formlarda hedefe yönelik olarak tasarlanan ve dolayısıyla kanser hücreleri üzerindeki antijenlere bağlanan monoklonal antikorlar geliştirilmekte ve kullanılmaktadır. $\mathrm{Bu}$ antikorlar, immünoglobülin $\mathrm{G}(\mathrm{IgG})^{\prime}$ ' nin $\mathrm{Fc}$ parçası üzerinden etki edip hücrede toksisiteye neden olur. Antikorların tümör merkezine nüfuz etmeleri boyutları dolayısıyla kisitlıdır. Ayrıca üretimleri oldukça maliyetlidir. Buna karşıllk, bir antikor molekülü kadar fonksiyonel olan nanokorların hem üretimi ucuz hem de boyutları küçüktür. Nanokorların immünterapötik etkisi $\mathrm{Fc}$ parçasının bulunmaması sebebiyle monoklonal antikorlara kıyasla daha azdır. Ancak bu durum, immün sistm kaynaklı yan etkilerinin de daha az görülmesini sağlar. Son zamanlarda yapılan çalışmalarda nanokorların radyoaktif çekirdeklere veya hücrelerin efektör kısmına bağlanabilme yetenekleri keşfedilmiştir [22]. Ayrıca nanokorlar, kansere karşı ilaçlar içeren nanoparçacıklar ve hedefe yönlendirmek üzere sitotoksik moleküller oluşturmada kullanılabilir [23].

Nanokorlar keşiflerinden itibaren ilk defa tümör hücre reseptörlerine antagonist olarak üretilmişlerdir. Antagonist nanokorlar, hücreleri kontrollü hücre ölümüne (apoptoz) götüren yolakları aktifleştirir. Nanokorların hedef aldığ 1 bu reseptörler ya sadece tümör hücrelerinde bulunur ya da normal hücrelerde de bulunup tümör hücrelerinde yüksek düzeyde ifade edilirler.

Epidermal büyüme faktörü reseptörü (EGFR) farklı kanser türlerinde yüksek düzeyde ifade edildiğinden, nanokorları bağlamak için güzel bir hedef haline gelmiştir. Meme kanseri hücrelerinde, hem insan epidermal büyüme faktörü reseptörü-2 (HER-2)" hem de "EGFR" ekspresyon düzeyleri yüksektir. Dolayısıyla, iki farklı reseptör aynı anda hedeflendiğinde kanser hücresinin direnç oluşturması zorlaştığından buna uygun nanokorlar üretilmeye çalışılmıştır. Bunun için bir anti-EGFR nanokoru ile iki adet anti-HER2 afikoru (affibody) birleştirilmiştir. $\mathrm{Bu}$ birleşim nanokor ve afikordan oluşturulmuş ve MaAbNA (multivalent antibody comprising nanobody and affibody moieties) ismi verilmiştir. (Afikorlar, antikorların taklitleridir ve Staphylococcus aureus bakterisinden üretilmişlerdir) [24]. MaAbNA' ya ek olarak kemoterapi ilac1 olan doxorubicin verilmesi daha da güçlü bir 
tümör karşıtı etkinin oluşmasını sağlamıştır. Bir başka çalışmada anti-EGFR nanokoru (i)RGD proteini ile birleştirilmiş ve birleşimin tümöre daha iyi penetre olduğu gözlemlenmiştir [25]. Ayrica bu füzyon proteininin, pactitaxel isimli kemoterapi ilacının etkinliğini arttırdığ bulunmuştur [26].

Nanokorlar modifiye edildiklerinde kanser hücreleri için daha ölümcül olabilmektedir. $\mathrm{Bu}$ amaçla, EGFR hedefleyen nanokorlardan bir türü de biyotinlenip streptavidin ile biyonanokapsüle bağlanarak modifiye edilmiştir [27]. Normal koşullarda boş nanoparçacıklar hepatositlere ilaç veya gen ulaştırılmasını sağlar. Ancak bu şekilde biyotinlenmiş olanlar, içerdikleri nanokorlar sayesinde EGFR üreten tümör hücrelerini hedef alabilmektedir.

Nanokorlar küçük boyutlu olduklarından kan beyin bariyerini rahat geçerler. Bu nedenle ölümcül beyin tümörlerinden biri olan GBM'nin tedavisinde kullanılabilirler. Dr. Shah ve ark., nöral kök hücrelerde EGFR'a özgü nanokorların, lentivirüsler aracılığıyla üretilmesini sağlamışlar ve tedavi amaçlı kullanıldığında bu nanokorların EGFR'a bağlanarak reseptörü inhibe ettiğini kanıtlamışlardır. Umut vaat eden devam çalışmalarında ise, lentiviral vektörler kullanılarak anti-EGFR nanokorlarına entegre edilen sitotoksik TRAIL'1 (ENb-TRAIL) ve Pseudomonas egzotoksini (ENb-PE) üretecek nöral kök hücreler oluşturulmuştur. Böylece glioblastoma beyin tümörüne uygulanan sitotoksik nanokor formlarının, hem hücre ölümüne/çoğalmasına giden yolakları hedef alarak hem de protein sentezini bloke ederek kanserin istilacı etkisini azalttığ 1 gösterilmiştir [28].

Tümörde yüksek oranda ekspresyonu olan bir başka protein ise CapG'dir. Hücre içi iskelette bulunur ve tümör metastazında önemli rol oynar. Metastazı önlemek için anti- CapG nanokorları transkorlar (transbody) olarak tasarlanmıştır. Burada nanokorlar, E.coli' den salgilanan protein F'nin T3S sinyali ile donatılmıştır [29] ve donatılan nanokor kanserli dokuya enjekte edilmiştir [30]. Bunlara ek olarak kanser hücrelerinin adezyonunda, göç etmelerinde, invazyonunda ve metastazında rol oynayan bir diğer protein olan uPA proteinini hedefleyen bir nanokor da üretilmiştir [31].

Bilindiği üzere, doğrudan kanser hücreleri hedef alınabildiği gibi tümör dokusunda damar oluşumunu (anjiyogenezi) durdurmak da metastazı önlemeye yardımcı olabilecek bir

Adress for correspondence: İstanbul Medipol Üniversitesi Tıp Fakültesi, Tıbbi Biyoloji ABD, Rejeneratif ve Restoratif Tıp Araştırmaları Merkezi (REMER), Ekinciler Caddesi No:19 Kavacık Kavşağı̆, Beykoz, İstanbul, Türkiye

e-mail: nkarakas@medipol.edu.tr

Available at www.actaoncologicaturcica.com

Copyright $\odot$ Ankara Onkoloji Hastanesi diğer yaklaşımdır. Bunun için G-protein bağlı kemokin reseptörüne antagonist nanokorların kullanımı, baş ve boyun bölgesinde bulunan kanserli dokularda küçülme görülmesini sağlamıştır [32]. Ayrıca kanser hücrelerinde yüksek düzeyde ifade edilen vasküler endotelyal büyüme faktörü-A (VEGF-A) ve vasküler endotelyal büyüme faktörü reseptörü2'ye karşı nanokorlar da geliştirilmiştir [33-35]. Kanser metastazında etkili bir faktör olan ve düşük oksijenli koşullarda salgılanan karbonik anhidraza karşı üretilen nanokorların ise tümör hücrelerinin canlılığını azalttığı görülmüştür [36].

Kandaki leptin miktarı, kanser riski ile doğru orantılı seyrettiği için leptin reseptörlerini nötralize eden nanokorların, kanser tedavisinde kullanılabileceği düşünülmüştür. Buradan hareketle, melanoma fare modelinde, lokal olarak anti-LepR nanokoru uygulanmasının tümör büyümesini engellediği gösterilmiştir. Diğer taraftan, sistemik olarak uygulandığında ise leptinin vücut için önemli etkilerini yerine getiremediği ve tümör karşıtı etkisinin de görülmediği saptanmıştır [37].

Nanokorlar, Fc efektör kismı bulunmamasına rağmen ilaçlara ya da büyük moleküllere taşıyıcılık yapabilirler. $\mathrm{Bu}$ da, ilaçların anti-tümör etkilerini arttırabilir ve sistemik zehirlenmeleri de azaltabilir. Bir antagonist nanokor ile bir molekülün fonksiyonel grubu bağlandığında tümöre özgünlük, tedavi edici etki ve dokuya nüfuz etme artar. VEGFR-2 ile Pseudomonas exotoxin A konjuge edilerek bu örneklendirilmiştir [38].

Tümör tedavisi için geliştirilen yeni yöntemlerden biri de kimerik antijen reseptörleri (CARs) bulunan $\mathrm{T}$ hücreleridir ve klinik denemeleri olumlu sonuçlar vermiştir. T hücresi terapisinde tümör antijenine özel $\mathrm{T}$ hücreleri üretilir. Burada dikkat edilmesi gereken $\mathrm{T}$ hücresinin antijene bağlanan kısmının immunojenisiteye sebep olmasıdır. Bu sorunun üstesinden gelebilmek için nanokorlar, bağlayıcı ve/veya hedefleyici moleküller olarak kullanılabilir [39, 40]. Böylece hem $\mathrm{T}$ hücresi tabanlı immünoterapi (dokuya iyi derecede nüfuz edebilme, sitokin salgılanmasi) hem de nanokor tabanlı immünoterapi (küçük boyut, düşük immünojenisite, tümör antijenine özgünlük) kullanılmış olur [41]. 


\section{Görüntüleme amaçlı yaklaşımlar}

Kanser araştırmaları ve tedavisi sırasında görüntüleme hayati önem taşır. Alınan her ilacın, atılan her adımın kanserli doku üzerindeki etkisini gözlemlemek doğru tedaviyi geliştirmek için önem arz eder. Bunun için çeşitli görüntüleme teknikleri ve görüntülemeye yardımcı moleküller üretilmiştir. Günümüzde tıbbi görüntülemede radyofarmasötiklerin kullanımı gittikçe yaygınlaşmaktadır. Bu tekniği tercih edilir kılan sadece kullanım kolaylığı değil; erken tanıda, hastalığın gelişiminde ve tedaviye verilen cevabı görmede de oldukça etkili olmasıdır. Nükleer görüntüleme (SPECT, PET), optik görüntüleme (NIR) ve mikrokabarcık (microbubble) kullanılarak ultrason ile görüntüleme klinikte kullanılan tekniklerden birkaçıdır. PET tarayıcılarının çözünürlüğü SPECT'ten daha yüksektir. NIR ile görüntüleme ise SPECT ve PET'ten çok daha kısa sürer. Ayrıca NIR daha hassas ve daha güvenlidir çünkü iyonlaştırıcı olmayan radyasyon kullanılır. Buna rağmen görüntüsü birkaç milimetre ile sınırlanmıştır ve genellikle yüzey terapilerini görüntülemede kullanılır [42].

Nanokorlar, hızlı ve seçici olarak tümör antijenlerine bağlanır. Bağlanmayanlar ise kandan hizlica temizlenir. Dr. Bannas ve arkadaşları, NIR floresan ile in vivo $\mathrm{T}$ hücresi görüntülemek için nanokorlar ile monoklonal antikorları AlexaFlour 680 ile işaretlemiş ve sonuçları karşılaştırmıştır. Buna göre nanokorların invazif olmayan kısa süreli kullanımında en iyisi olduğuna karar vermiştir [43]. Buna karşın kandan çabuk temizlenmesi yo görüntüleme sirasinda beklenmeyen farmakolojik etkiye ve böbrek tutulumuna sebep olur, bu da yakın organlardaki lezyonları gözlemlemeyi zorlaştırır [44]. Ayrica görüntüleme sirasinda ters farmakolojik etkiye sebep olabiliceğinden nanokorlardan hiçbir agonistik aktivite göstermemeleri beklenir [45].

Hepatosit büyüme faktörü (HGF), HER-2, prostat spesifik zar antijeni (PSMA), karsinoembriyonik antijen (CEA) veya CIAX ile hedefe yönelik nanokorlar, invazif olmayan klinik öncesi taramalar için geliştirilmiştir [4654]. (Örneğin; meme kanseri, prostat kanseri). EGFR-spesifik nanokor ile Teknesyum (Tc) ya da Galyum (Ga)'un birleştirilmesi nükleer görüntülemede, Florofor IRDye $800 \mathrm{CW}$ ile birleştirilmesi NIR'da kullanılmaktadır. MRI ve NIR bir arada kullanılıp; insulin benzeri büyüme faktörü bağlayıcı protein 7 (IGFBP7)'ye karş1 kullanılan nanokor ile fonksiyonelleştirildiğinde çok daha hassas sonuçlar elde edilmiştir (IGFBP7 beyin tümörü damarlarında aşırı üretilir). Bu ikili spektral görüntüleme tümör/arka plan oranını arttırır ve böylece heterojen tümörlerin erken teşhisine yardımcı olur [55]. Ayrıca, yapılan son çalışmalarda nanokabarcıklar PSMA-spesifik nanokorlar ile birleştirilerek prostat kanseri görüntülemesini kolaylaştırmıştır [56].

Bir başka görüntüleme tekniği ise kuantum noktaları kullanılarak mikrofoton mikroskobunda görüntülemedir. Nanokorlarla birleştirildiğinde immün işaretlemede kullanılabilir [57].

Moleküler görüntülemede kullanılan nanokorlar, sadece hastalığın tanısına ve gelişimini gözlemlemeye değil farklı amaçlara da hizmet edebilir. Örneğin; NIR'ın görüntüleme rehberliğindeki ameliyatlarda çok yardımcı olduğu ortaya çıkmıştır. Anti-EGFR $\mathrm{Nb}$ 7D12 ile IRDye800CW'nin konjuge edilmesiyle ortopedik dil tümörlerinin rezeksiyonu sırasında cerraha tümörün gerçek zamanlı görüntülerinin ulaşmasını sağlar.

\section{$b$ - Enfeksiyon \\ Viral Enfeksiyon}

Nanokorlar, viral replikasyon döngüsünün her seviyesinde etki gösterebildiklerinden, virüslerin hücreye tutunmasını, hücre içine girmesini ve hatta çoğalmasını engellemektedir. Özellikle insan immün yetmezlik virüsü (HIV), Hepatit C virüsü $(\mathrm{HCV})$ ve Domuz üreme ve solunum sendromu virüsü (PRRSV) gibi viral hastalıkların tedavisinde etkilidir.

Nanokorlar farklı epitopları hedefleyen farklı VHH'lerin multimerizasyonu şeklinde ya da monovalent antikorlara izolösin fermuarı eklenerek biçimlendirilebilir. (Izolösin fermuarı eklemek translasyondan sonra trimerizasyona neden olur.) $\mathrm{Bu}$ çalışmalar neticesinde, nanokorların viral antijenlere ilgisi ve bağlanabilirliği arttırılmıştır [22, 58-60]. Gelişen teknoloji ile birlikte profilaktik (hastalığ1 önleyici) nanokor üretimi de mümkündür. Genetik olarak modifiye edilmiş laktobasililer, laktokor (lactobody) adı verilen VHH antikor fragmentleri üretebilmektedir. Yüzeyinde antirota virüs nanokoru bulunan laktokorların oral formu rotavirüslerden kaynaklanan ishallere karşı profilaktik olabilir. Profilaktik kullanımı haricinde, lactobacillus paracasei tarafindan üretilen çiftli nanokorlar ya da birlikte çalışan tekli nanokorlar mutant virüslerin kaçmasını 
engelleyerek tedavi amaçlı da kullanılabilirler. [17, 61-64].

\section{Mantar ve Parazit Enfeksiyonu}

Nanokorlarin parazitlere karşı kullanımı yeni yaygınlaşan bir alandır. Trypanosoma brucei parazitleri yüzeylerindeki değişken özgül yüzey glikoproteinlerindeki (VSG) antijen çeşitliliği sayesinde antikor tedavilerine karşı direnç oluşturmuşlardır. Küçük boyutları sayesinde antikorların ulaşamadığı VSG epitoplarına bile erişebilen nanokorlar, etkili bir tedavi yöntemi olabilir.

Yapılan bir çalışmada, parazitin yüzeyinde aktif olan ß-lactamaz enzimi ve trypanolitik olmayan VSG'ye özgü nanokorlarin birleştirtirilmesiyle bir immüntoksin molekülü geliştirilmiştir. $\mathrm{Bu}$ immüntoksin, cephalosporin mustard ilacını yüksek toksisiteye sahip PDM'ye çevirerek parazitin ölümüne sebep olur [65]. Afrika tyrpanosomiasis hemolenfatik fazında tedavi edilebilen bir parazittir. Fakat, ensefalik faza geçtiğinde kan-beyin bariyeri devreye girdiğindendaha tehlikeli bir hal alır. Dolayısıyla nanokorlar kan-beyin bariyerini geçebildiğinden ensefalik fazın tedavisinde de kullanılabilir. Caljon ve ark. "An33" nanokorunun sağliklı bir bireyin kan-beyin bariyerini geçebildiğini ve hatta patolojik durumlarda geçişin daha fazla olduğunu keşfetmiştir [66].

Parazitlere karşı olduğu gibi mantarlara karşı da etkili olabilen nanokorların bir diğer kullanım alanı ise medikal şampuanlardır. Malassezia furfur mantarının insanda kepek oluşumuna sebep olduğu bilinmektedir. Hücre duvarı proteini Malf1'e karşı üretilen nanokorlar şampuanda yap1sı bozulmadan kalabilmekte ve kepek oluşumunu engellemektedir. Nanokorlar yüksek üre derişiminde yapısını koruyabildiği için bu tür uygulamalara açıktır [12].

\section{Bakteri enfeksiyonu}

Bakteriyel hastalıklara karşı uygulanan antibiyotik tedavisinin pahalı olması, bakterilerin antibiyotiklere karşı direnç oluşturması ve vücutta yaşayan yararlı bakterileri de öldürmesi sebebiyle yeni tedavi yöntemlerine ihtiyaç duyulmaktadır. Nanokorlar bu noktada devreye girmekte ve bakteri yüzeyindeki proteinlere bağlanarak onların vücut hücrelerine tutunmasina engel olmaktadir. Ayrica, nanokorlarła bakterilerin flagellalarını hedef alarak hareketliliklerini kaybetmelerini sağlayabilir ve biyofilm oluşturmalarını
Pseudomonas aeruginosa'ya karşı antiflagellin nanokorları kullanılarak yapılmıştır [67]. Nanokorlar doğrudan bakterilere saldırmak yerine bakterilerin ürettiği patojenik enzimlere saldırabilirler. Ayrıca bakterilerin antibiyotiklere karşı oluşturdukları direnci kırmak için de kullanılabilirler. $\mathrm{Bu}$ amaçla nanokorlar, $\beta$ laktamazın iki çeşidi (TEM-1 ve BcII) için antibiyotik direncini yok etmede kullanılır [68]. Her ne kadar nanokorlar bu direnci kırmakta etkili olsa da kurtulan bakterilerin ürettiği yeni enzim çeşitleri direncin tekrar oluşmasına sebep olabilir.

\section{$c$ - Enflamasyon}

Enflamasyon, vücutta görülebilecek her türlü yara ve enfeksiyona karşı vücudun savunma mekanizmasıdır. Genel olarak akut safhada görülen enflamasyon vücudun iyileşmesine ya da patojene karşı mücadele etmesine yardımcı olur. Fakat akut safhanın kroniğe dönüşmesi ve uzun süre bu mekanizmanın devrede kalması birçok otoimmün hastalığ 1 da beraberinde getirmektedir. Bunların tedavisinde günümüzde anti-enflamatuar ilaçlar kullanılmaktadır. Ancak bu ilaçlar pahalı olmaları, yeterince özgün olmamaları ve vücutta farklı yan etkilere sebep olmaları nedeniyle alternatif yollar aranmaktadir. $\mathrm{Bu}$ noktada da nanokorlar devreye girmektedir.

\section{Otoimmün ve enflamatuar hastaliklar}

Bilindiği üzeretümör nekroz faktörü (TNF), enflamasyonda önemli bir rol oynamaktadır. TNF reseptörlerini bloke etmek için geliştirilen nanokorlar, enflamasyonun baskılamasında etkilidir. Ancak TNF reseptörlerinin tamamının bloke edilmesi istenmeyen etkiler oluşturmaktadır. $\mathrm{Bu}$ nedenle daha spesifik nanokorlarüretilmiştir ve bu nanokorlar doğrudan tümör nekroz faktörü reseptörü-1 (TNFR-1)'e bağlanmakta ve daha çok reseptörün enflamasyon başlatıcı bölgesine etki etmektedir. TNFR1'e bağlanmak için albümin proteinine bağlı nanokorlar ile TNF rekabet etmektedir ve böylece bu nanokorlar, TNFR baskılayıc1 etki göstermektedir [48]. In vivo, ex vivo ve in vitro çalışmalar göstermiştir ki nanokorlar, TNFR1 inhibisyonunda başarılı olduğu için anti-TNF tedavilerine alternatif olarak kullanılabilir. Ancak multiple skleroz gibi anti-TNF tedavisinin sonuç vermediği hastalıklarda nanokor tedavisinin etkinliği ile ilgili çalışmalara ihtiyaç vardır [69]. Bunlara ek olarak otoimmün hastalıklar, anti-IgG 
nanokorlarla oto-IgG'lerin kandan süzülerek atılması sağlanarak tedavi edilebilir. Sistemik lupus eritematozus (SLE) ve good pasture column (GPC) hastalarında anti-IgG nanokorları, IgG'lere bağlanarak otoimmünite oluşmasını önleyip kandan temizlenebilmektedir [70]. Bu yöntem IgG kaynaklı diğer otoimmün hastalıkların da tedavisinde kullanılabilir.

\section{Sistemik Enflamatuar Cevap Sendromu}

Sistemik enflamatuar cevap sendromu (SIRS), pro-enflamatuar ve anti-enflamatuar yolaklar arasındaki hassas dengenin bozulmasından kaynaklanan kontrolsüz inflamatuar cevap verme durumudur. Eğer bu duruma bir enfeksiyon sebep oluyorsa bu durum "sepsis" olarak adlandırılır. Yoğun bakım hastalarında en sık görülen ölüm sebeplerinden biri SIRS'tır. Bu hastalığın yalnızca semptomatik tedavisi mümkündür. Birçok farklı patolojik durumun bir arada görülmesi ve uygun tedavi yöntemi oluşturulamaması bu durumun başlica sebeplerindendir. Heterojen popülasyonu daha homojen alt gruplara ayırmak için iyi biyobelirteçlere ihtiyaç vardır. Prokalsitonin (PCT) bu alanda kullanılan, sepsise veya septik şoka girme ihtimali olan hastalarda tanı koymayı sağlayan bir biyo-belirteçtir. Kandaki PCT seviyesini yüksek finitede tanıyan nanokorlar tanı koymada yardımcı bir araç olabilirler [71, 72]. Teşhis koymanın yanı sıra tedavi amaçlı nanokor kullanımı da bu ölümcül hastalıklar için çok önemlidir. Lipopolisakkarit (LPS), gram negatif bakterilerin diş zarından salınan ve immün hücrelere yüksek miktarda enflamatuar mediyatörler salgılatan bir moleküldür. $\mathrm{Bu}$ molekülün immün hücrelerde MMP-8 salg1lattığ1 ve MMP-8'in proenflamatuar olduğu kanıtlanmıştır [73-75]. Ayrıca yüksek ölüm oranlarıyla uyumluluk gösterdiği bilinir. Nanokor-14, MMP-8'i hedeflemek için üretilmiş yeni bir nanokordur. Demeestre ve ark., MMP-8'in nanokor-14 ile inhibe edilebildiğini in vitro deneylerle göstermiştir. Ayrıca, kas dokusunda elektroporasyon yöntemi ile sistemik nanokor14 üretmenin mümkün olduğunu ve LPS kaynaklı endotoksisiteye karşı koruma oluşturabileceğini in vivo deneylerle kanıtlamışlardır [76]. Anti-LPS antikorlar klinik denemelerde başarılı olmamasına karşılık, antiLPS nanokorlar seçici plazmaferez sırasında LPS'in vücuttan uzaklaştırılmasında etkili olabilirler.

\section{Immünterapi}

Geçmiş araştırmalar sitokinlerin pro- enflamatuar özelliğini azaltmak üzerine yoğunlaşmıştır. Ancak bu alanda yapılan çalışmalara göre sitokinlerin anti-enflamatuar, anti-kanser ve anti-viral gibi birçok özelliğe sahip olduğu ortaya çımıștır. Sitokinlerle yapılan çalışmalarda hücre içi toksisiteyi arttırdıkları görüldüğünden, çalışmalar rafa kaldırılmıştır. Ancak bu durum immünositokinlerle tersine çevirilebilir. İmmünositokinler, genetik olarak geliştirilmiş daha az toksik ve/veya daha az aktif formlara dönüştürülmüş sitokinlere, nanokorların eklenmiş halidir. Bu yolla mutant tip-1 IFN'ler murin-leptin reseptörlerini (MLR) hedefleyen nanokorlarla birleştirilmiş ve antiviral etkisi gösterilmiştir [77]. Buna benzer araştırmalarda, sitokini veya hedeflenen bölgeye uygun nanokoru değiştirerek virus ile enfekte olmus hücreleri, tümör hücrelerini, bağ $1 s ̧ 1 k l 1 k$ sistemi hücrelerini de hedeflemek mümkündür.

\section{$d$ - Nörodejeneratif hastalıklar}

Günümüzde nörodejeneratif hastalıklar için sadece bulgu niteliğinde tedavi uygulanmakla beraber hastalığın izlediği yolu değiştirebilecek uygun bir nöron koruyucu tedavi bulunamamaktadır. Bununla birlikte bu tür hastalıklar, sağlık hizmetlerindeki ekonomik yükün büyük bir bölümünü oluşturmaktadır ve popülasyonun yaşlanmasıyla beraber harcanması gereken maddi yük de bununla beraber artacaktır [78]. Dolayısıyla yeni ve uygun fiyatlı tedavi yöntemlerinin geliştirilmesi gerekmektedir.

\section{Alzheimer Hastalı̆̆ı}

Alzheimer, en sik rastlanan nörodejeneratif hastalıkların başında gelir. Amyloid- $\beta$ (Aß) peptit plaklarının sinir dokusunun hücre dışı sıvısında birikmesi ile oluşur. Bununla beraber hücre içinde biriken Tau proteinleri nörofibril yumaklarına dönüşür [79]. Zamanla bunama ve bilişsel fonksiyonlarda kayıplar görülür. $A ß$ plakları, amyloid öncü proteinlerinin (APP) proteolitik yıkımları sonucunda oluşur. $\mathrm{Bu}$ işi yapan enzime, beta sekretaz, ß-bölgesi APPyıkım enzimi (BACE-1) adı verilir. Farklı öncül proteinler için farklı nanokorlar üretilmeye başlanmıştır ve bu nanokorlar $A ß$ protofibrillerini sabitleyerek olgun $A B$ fibrillerinin oluşumunu önler [80, 81]. Bununla beraber $A B$ protofibrillerini sabitleyerek AB birikmesinin önlenebilirliği hala tartışılan bir konudur [82]. Son zamanlarda Aß plaklarının iki farklı epitopunu hedefleyen nanokor tasarlanmıştır. 
Ancak başlatılan klinik denemeler olgunlaşamadan sonlanmıştır. Deneylerde ilaç ile ilgili yan etkiler görülmüş ve ilacın $A ß$ birikmesini azaltması beklenirken arttırdığ gözlemlenmiştir. Bunun da iki farklı epitopu hedeflemesinden dolayı olduğu düşünülmektedir. Böylece $A ß$ hedefleme stratejisi yerini BACE-1 inhibe edici nanokorlara bırakmıştır ve bu amaca uygun nanokorlar oluşturulmuştur. Tanıda kullanmak için hasarlı kan-beyin bariyerini geçebilen nanokorlar geliştirilmiştir. Aß’ya özgü bu nanokorlar Tc ile etkinleştirilmiş, vasküler ve parankimal AB plaklarını tespit etmede kullanılmıştır [83].

\section{Parkinson Hastalı̆̆}

İkinci en sık görülen nörodejeneratif hastalık olan Parkinson'u tedavi etmek için de nanokorlar kullanılmaya başlanmıştır. Parkinson, "substantia nigra"da bulunan dopaminerjik nöronların kaybı olarak tanımlanır. Ayrıca $\alpha$ synuclein ( $\alpha$-syn)'in yanlış katlanması sonucu fibril formunda birikmesinin de hastalığın patogenezinde rol oynadığı düşünülmektedir [79]. Dolayısıyla hücre içi $\alpha$-syn miktarını azaltmak tedavi için mantıklı bir yaklaşımdır [84]. NbSyn2'nin monomerik $\alpha$-syn'e bağlanarak birikimini azaltacağı düşünülmüştür. Ancak nanokorlar, daha önceden oluşmuş fibril yumaklarına da bağlanabildiğinden fibril birikmesi engellenememiştir [85, 86]. Daha sonra üretilen NbSyn87, NbSyn2'den farklı epitopları tanıdığı halde hem monomerik hem de fibril formuna bağlandığı için etkili olamamıştır. Yine de bu denemeler $\alpha$-syn yapısına dair değerli bilgiler kazandırmıştır [87].

\section{Huntington Hastalı̆̆}

Huntington, otozomal dominant geçişli nöropsikiyatrik bir hastalıktır. Kas koordinasyonunu etkilemekle beraber davranış bozukluklarına da sebep olur. $\mathrm{Bu}$ hastalık, mutant Huntington proteininin (mHTT) yanlış katlanması sonucu oluşur ve doğrudan bu proteinin mutant formunu hedefleyen tedavi yaklaşımları öne çıkmaktadır [88]. Huntington riski taşıyan hastalara genetik tarama yapılarak belirtiler başlamadan önce tanı koyulabilir. Buna rağmen antikorlar ya da scFv'ler kullanılarak yapılan sayısız çalışma varken sadece bir adet nanokor geliştirildiği rapor edilmiştir [89].

Oculopharyngeal kas distrofisi (OPMD) de Huntington ile benzer özellikler taşıyan bir hastalıktır. Huntinton'a kiyasla OPMD'de spesifik bir kas grubunda distrofi gözlenir ve bu Kavacık Kavşă̆ı̆, Beykoz, İstanbul, Türkiye e-mail: nkarakas@medipol.edu.tr

Copyright $\odot$ Ankara Onkoloji Hastanesi

hastalığın patolojisi PABN1 geninde oluşan mutasyona dayanmaktadır. Mutant genin $\alpha$ helikal kısmına bağlanabilen bir nanokor geliştirilmiştir. $\mathrm{Bu}$ nanokorun, Nb3F5 intrakor (intrabody) olarak başarılı bir şekilde ekprese edildiği gösterilmiştir. Ayrıca hücresel OPMD modelinde sadece birikimi engellemekle kalmamış, birikmiş proteinleri de temizlemiştir [90].

\section{Nanokorların geleceği}

Antikorların fonksiyonel en küçük birimi olarak tanımlanan nanokorlar, küçük boyutları ve modüleriteleri sayesinde dokuya nüfuz edebilmekte ve üstelik antikorların ulaşamadığ bölgelere kadar erişebilmektedir. Bu yetenekleri ile nanokorlar, kanser başta olmak üzere enfeksiyon hastalıklarından nörodejeneratif hastalıklara kadar pek çok hastalığın teşhis ve tedavisine yönelik avantajlar sunmaktadır. $\mathrm{Bu}$ bilgiler 1şı̆̆ında, mevcut nanokorlara ek olarak profilaktik terapötiklerin ve moleküler görüntüleme ajanlarının temelini oluşturacak yeni nanokorların geliştirilmektedir.

\section{REFERANSLAR}

1. Lipman, N.S., et al., Monoclonal versus polyclonal antibodies: distinguishing characteristics, applications, and information resources. ILAR J, 2005. 46(3): p. 258-68.

2. Olafsen, T. and A.M. Wu, Antibody vectors for imaging. Semin Nucl Med, 2010. 40(3): p. 16781.

3. Hamers-Casterman, C., et al., Naturally occurring antibodies devoid of light chains. Nature, 1993. 363(6428): p. 446-8.

4. Arbabi Ghahroudi, M., et al., Selection and identification of single domain antibody fragments from camel heavy-chain antibodies. FEBS Lett, 1997. 414(3): p. 521-6.

5. Arbabi-Ghahroudi, M., J. Tanha, and R. MacKenzie, Isolation of monoclonal antibody fragments from phage display libraries. Methods Mol Biol, 2009. 502: p. 341-64.

6. Muyldermans, S., et al., Camelid immunoglobulins and nanobody technology. Vet Immunol Immunopathol, 2009. 128(1-3): p. 178-83.

7. Muyldermans, S., Nanobodies: natural singledomain antibodies. Annu Rev Biochem, 2013. 82: p. 775-97.

8. Pardon, E., et al., A general protocol for the generation of Nanobodies for structural biology. Nat Protoc, 2014. 9(3): p. 674-93.

9. Lauwereys, M., et al., Potent enzyme inhibitors derived from dromedary heavy-chain antibodies. EMBO J, 1998. 17(13): p. 3512-20.

10. Perez, J.M., et al., Thermal unfolding of a llama antibody fragment: a two-state reversible process. Biochemistry, 2001. 40(1): p. 74-83.

11. Dumoulin, M., et al., Single-domain antibody fragments with high conformational stability. oratif Tıp Araştırmaları Merkezi (REMER), Ekinciler Caddesi No:19 
Protein Sci, 2002. 11(3): p. 500-15.

12. Dolk, E., et al., Isolation of llama antibody fragments for prevention of dandruff by phage display in shampoo. Applied and Environmental Microbiology, 2005. 71(1): p. 442-450.

13. Hussack, G., et al., Engineered single-domain antibodies with high protease resistance and thermal stability. PLoS One, 2011. 6(11): p. e28218.

14. Harmsen, M.M., et al., Prolonged in vivo residence times of llama single-domain antibody fragments in pigs by binding to porcine immunoglobulins. Vaccine, 2005. 23(41): p. 4926-4934.

15. Tijink, B.M., et al., Improved tumor targeting of anti-epidermal growth factor receptor Nanobodies through albumin binding: taking advantage of modular Nanobody technology. Molecular Cancer Therapeutics, 2008. 7(8): p. 2288-2297.

16. Kontermann, R.E., Strategies for extended serum half-life of protein therapeutics. Current Opinion in Biotechnology, 2011. 22(6): p. 868876.

17. Pant, N., et al., Lactobacilli expressing variable domain of llama heavy-chain antibody fragments (lactobodies) confer protection against rotavirusinduced diarrhea. J Infect Dis, 2006. 194(11): p. $1580-8$.

18. Carlson, J.R., A new means of inducibly inactivating a cellular protein. Mol Cell Biol, 1988. 8(6): p. 2638-46.

19. Rothbauer, U., et al., Targeting and tracing antigens in live cells with fluorescent nanobodies. Nature Methods, 2006. 3(11): p. 887-889.

20. Huang, Y.P., et al., Interactions between Metalbinding Domains Modulate Intracellular Targeting of $\mathrm{Cu}(\mathrm{I})$-ATPase ATP7B, as Revealed by Nanobody Binding. Journal of Biological Chemistry, 2014. 289(47).

21. Kaiser, P.D., et al., Recent progress in generating intracellular functional antibody fragments to target and trace cellular components in living cells. Biochimica Et Biophysica ActaProteins and Proteomics, 2014. 1844(11): p. 1933-1942.

22. Hultberg, A., et al., Llama-Derived Single Domain Antibodies to Build Multivalent, Superpotent and Broadened Neutralizing AntiViral Molecules. Plos One, 2011. 6(4).

23. Kijanka, M., et al., Rapid optical imaging of human breast tumour xenografts using anti-HER2 VHHs site-directly conjugated to IRDye $800 \mathrm{CW}$ for image- guided surgery. European Journal of Nuclear Medicine and Molecular Imaging, 2013. 40(11): p. 1718-1729.

24. Ding, L., et al., Small sized EGFR1 and HER2 specific bifunctional antibody for targeted cancer therapy. Theranostics, 2015. 5(4): p. 378-98.

25. Sha, H., et al., Tumor-penetrating peptide fused EGFR single-domain antibody enhances cancer drug penetration into 3D multicellular spheroids and facilitates effective gastric cancer therapy. J Control Release, 2015. 200: p. 188-200.

26. Sha, H., et al., A tumor-penetrating recombinant protein anti-EGFR-iRGD enhance efficacy of paclitaxel in 3D multicellular spheroids and gastric cancer in vivo. Eur J Pharm Sci, 2015. 77: p. 60-72.
27. Shishido, T., et al., Biotinylated Bionanocapsules for Displaying Diverse Ligands Toward Cell-specific Delivery. Journal of Biochemistry, 2009. 146(6): p. 867-874.

28. Zhu, Y., et al., Bi-specific molecule against EGFR and death receptors simultaneously targets proliferation and death pathways in tumors. Sci Rep, 2017. 7(1): p. 2602.

29. Blanco-Toribio, A., et al., Direct Injection of Functional Single-Domain Antibodies from E. coli into Human Cells. Plos One, 2010. 5(12).

30. Van Impe, K., et al., A nanobody targeting the Factin capping protein $\mathrm{CapG}$ restrains breast cancer metastasis. Breast Cancer Research, 2013. 15(6).

31. Kaczmarek, J.Z. and P.D. Skottrup, Selection and characterization of camelid nanobodies towards urokinase-type plasminogen activator. Molecular Immunology, 2015. 65(2): p. 384-390.

32. Maussang, D., et al., Llama-derived Single Variable Domains (Nanobodies) Directed against Chemokine Receptor CXCR7 Reduce Head and Neck Cancer Cell Growth in Vivo. Journal of Biological Chemistry, 2013. 288(41): p. 2956229572.

33. Behdani, M., et al., Expression, purification, and characterization of a diabody against the most important angiogenesis cell receptor: Vascular endothelial growth factor receptor 2. Adv Biomed Res, 2012. 1: p. 34.

34. Farajpour, Z., et al., A nanobody directed to a functional epitope on VEGF, as a novel strategy for cancer treatment. Biochem Biophys Res Commun, 2014. 446(1): p. 132-6.

35. Ebrahimizadeh, W., et al., Production of Novel VHH Nanobody Inhibiting Angiogenesis by Targeting Binding Site of VEGF. Appl Biochem Biotechnol, 2015. 176(7): p. 1985-95.

36. Araste, F., et al., A novel VHH nanobody against the active site (the CA domain) of tumor- associated, carbonic anhydrase isoform IX and its usefulness for cancer diagnosis. Biotechnol Lett, 2014. 36(1): p. 21-8.

37. McMurphy, T., et al., The anti-tumor activity of a neutralizing nanobody targeting leptin receptor in a mouse model of melanoma. PLoS One, 2014. 9(2): p. e89895.

38. Behdani, M., et al., Development of VEGFR2specific Nanobody Pseudomonas exotoxin A conjugated to provide efficient inhibition of tumor cell growth. New Biotechnology, 2013. 30(2): p. 205-209.

39. Rosenberg, S.A., et al., Adoptive cell transfer: a clinical path to effective cancer immunotherapy. Nature Reviews Cancer, 2008. 8(4): p. 299-308.

40. Sharifzadeh, Z., et al., Genetically engineered $T$ cells bearing chimeric nanoconstructed receptors harboring TAG-72-specific camelid single domain antibodies as targeting agents. Cancer Letters, 2013. 334(2): p. 237-244.

41. Baxevanis, C.N. and M. Papamichail, Targeting of tumor cells by lymphocytes engineered to express chimeric receptor genes. Cancer Immunology Immunotherapy, 2004. 53(10): p. 893-903.

42. Kosaka, N., et al., Clinical implications of nearinfrared fluorescence imaging in cancer. Future Oncology, 2009. 5(9): p. 1501-1511.

43. Bannas, P., et al., In vivo near-infrared fluorescence targeting of $\mathrm{T}$ cells: comparison of nanobodies and conventional monoclonal 
antibodies. Contrast Media \& Molecular Imaging, 2014. 9(2): p. 135-142.

44. Movahedi, K., et al., Nanobody-Based Targeting of the Macrophage Mannose Receptor for Effective In Vivo Imaging of TumorAssociated Macrophages. Cancer Research, 2012. 72(16): p. 4165-4177.

45. Henriksen, G. and F. Willoch, Imaging of opioid receptors in the central nervous system. Brain, 2008. 131: p. 1171-1196.

46. Vaneycken, I., et al., In Vitro Analysis and In Vivo Tumor Targeting of a Humanized, Grafted Nanobody in Mice Using Pinhole SPECT/Micro-CT. Journal of Nuclear Medicine, 2010. 51(7): p. 1099-1106.

47. Vaneycken, I., et al., Preclinical screening of anti-HER2 nanobodies for molecular imaging of breast cancer. Faseb Journal, 2011. 25(7): p. 24332446.

48. Pruszynski, M., et al., Targeting breast carcinoma with radioiodinated anti-HER2 Nanobody. Nuclear Medicine and Biology, 2013. 40(1): p. 52-59.

49. Xavier, C., et al., Synthesis, Preclinical Validation, Dosimetry, and Toxicity of Ga-68NOTA- Anti-HER2 Nanobodies for iPET Imaging of HER2 Receptor Expression in Cancer. Journal of Nuclear Medicine, 2013. 54(5): p. 776-784.

50. Evazalipour, M., et al., Generation and characterization of nanobodies targeting PSMA for molecular imaging of prostate cancer. Contrast Media \& Molecular Imaging, 2014. 9(3): p. 211220.

51. Massa, S., et al., Site-Specific Labeling of Cysteine-Tagged Camelid Single-Domain Antibody- Fragments for Use in Molecular Imaging. Bioconjugate Chemistry, 2014. 25(5): p. 979-988.

52. Chatalic, K.L.S., et al., A Novel In-111-Labeled Anti-Prostate-Specific Membrane Antigen Nanobody for Targeted SPECT/CT Imaging of Prostate Cancer. Journal of Nuclear Medicine, 2015. 56(7): p. 1094-1099.

53. Vaidyanathan, G., et al., Preclinical Evaluation of F-18-Labeled Anti-HER2 Nanobody Conjugates for Imaging HER2 Receptor Expression by Immuno-PET. Journal of Nuclear Medicine, 2016. 57(6): p. 967-973.

54. van Brussel, A.S.A., et al., Hypoxia-Targeting Fluorescent Nanobodies for Optical Molecular Imaging of Pre-Invasive Breast Cancer. Molecular Imaging and Biology, 2016. 18(4): p. 535-544.

55. Kijanka, M.M., et al., Optical imaging of preinvasive breast cancer with a combination of VHHs targeting CAIX and HER2 increases contrast and facilitates tumour characterization. Ejnmmi Research, 2016. 6.

56. Fan, X.Z., et al., Ultrasonic Nanobubbles Carrying Anti-PSMA Nanobody: Construction and Application in Prostate Cancer-Targeted Imaging. Plos One, 2015. 10(6).

57. Sukhanova, A., et al., Oriented conjugates of single-domain antibodies and quantum dots: toward a new generation of ultrasmall diagnostic nanoprobes. Nanomedicine-Nanotechnology Biology and Medicine, 2012. 8(4): p. 516-525.

58. Tillib, S.V., et al., Formatted single-domain

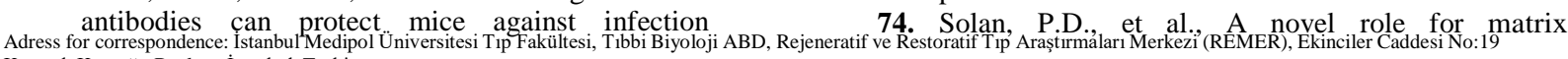
Kavacık Kavşağı, Beykoz, İstanbul, Türkiye e-mail: nkarakas@medipol.edu.tr with influenza virus (H5N2). Antiviral Research, 2013. 97(3): p. 245-254.

59. McCoy, L.E., et al., Molecular Evolution of Broadly Neutralizing Llama Antibodies to the CD4- Binding Site of HIV-1. Plos Pathogens, 2014. 10(12).

60. Dreja, H., et al., CD4 binding site broadly neutralizing antibody selection of HIV-1 escape mutants. Journal of General Virology, 2015. 96: p. 1899-1905.

61. Van der Vaart, J.M., et al., Reduction in morbidity of rotavirus induced diarrhoea in mice by yeast produced monovalent llama-derived antibody fragments. Vaccine, 2006. 24(19): p. 4130-4137.

62. Martin, M.C., et al., Integrative Expression System for Delivery of Antibody Fragments by Lactobacilli. Applied and Environmental Microbiology, 2011. 77(6): p. 2174-2179.

63. Pant, N., et al., Lactobacilli producing bispecific llama-derived anti-rotavirus proteins in vivo for rotavirus-induced diarrhea. Future Microbiology, 2011. 6(5): p. 583-593.

64. Gunaydin, G., et al., Co-Expression of AntiRotavirus Proteins (Llama VHH Antibody Fragments) in Lactobacillus: Development and Functionality of Vectors Containing Two Expression Cassettes in Tandem. Plos One, 2014. 9(4)

65. Stijlemans, B., et al., Efficient targeting of conserved cryptic epitopes of infectious agents by single domain antibodies - African trypanosomes as paradigm. Journal of Biological Chemistry, 2004. 279(2): p. 1256-1261.

66. Caljon, G., et al., Using microdialysis to analyse the passage of monovalent nanobodies through the blood-brain barrier. British Journal of Pharmacology, 2012. 165(7): p. 2341-2353.

67. Adams, H., et al., Inhibition of biofilm formation by Camelid single-domain antibodies against the flagellum of Pseudomonas aeruginosa. Journal of Biotechnology, 2014. 186: p. 66-73.

68. Conrath, K.E., et al., Beta-lactamase inhibitors derived from single-domain antibody fragments elicited in the Camelidae. Antimicrobial Agents and Chemotherapy, 2001. 45(10): p. 2807-2812.

69. Eugster, H.P., et al., Severity of symptoms and demyelination in MOG-induced EAE depends on TNFR1. European Journal of Immunology, 1999. 29(2): p. 626-632.

70. Klooster, R., et al., Improved anti-IgG and HSA affinity ligands: Clinical application of VHH antibody technology. Journal of Immunological Methods, 2007. 324(1-2): p. 1-12.

71. $\mathrm{Li}, \quad$ H.N., et al., A nanobody-based electrochemiluminescent immunosensor for sensitive detection of human procalcitonin. Analyst, 2014. 139(15): p. 3718-3721.

72. Yan, J.R., et al., Characterization and applications of Nanobodies against human procalcitonin selected from a novel naive Nanobody phage display library. Journal of Nanobiotechnology, 2015. 13.

73. Dejonckheere, E., R.E. Vandenbroucke, and C. Libert, Matrix metalloproteinase8 has a central role in inflammatory disorders and cancer progression. Cytokine \& Growth Factor Reviews, 2011. 22(2): p. 73-81. 
metalloproteinase- 8 in sepsis. Critical Care Medicine, 2012. 40(2): p. 379-387.

75. Vandenbroucke, R.E., et al., Matrix Metalloprotease 8-Dependent Extracellular Matrix Cleavage at the Blood-CSF Barrier Contributes to Lethality during Systemic Inflammatory Diseases. Journal of Neuroscience, 2012. 32(29): p. 9805-9816.

76. Demeestere, D., et al., Development and Validation of a Small Single-domain Antibody That Effectively Inhibits Matrix Metalloproteinase 8. Molecular Therapy, 2016. 24(5): p. 890-902.

77. Garcin, G., et al., High efficiency cell-specific targeting of cytokine activity. Nature Communications, 2014. 5.

78. Waldmeier, P.C. and W.G. Tatton, Interrupting apoptosis in neurodegenerative disease: potential for effective therapy? Drug Discovery Today, 2004. 9(5): p. 210-218.

79. Goedert, M., Alzheimer's and Parkinson's diseases: The prion concept in relation to assembled A beta, tau, and alpha-synuclein. Science, 2015. 349(6248).

80. Habicht, G., et al., Directed selection of a conformational antibody domain that prevents mature amyloid fibril formation by stabilizing A beta protofibrils. Proceedings of the National Academy of Sciences of the United States of America, 2007. 104(49): p. 19232-19237.

81. Lafaye, P., et al., Single-domain antibodies recognize selectively small oligomeric forms of amyloid beta, prevent A beta-induced neurotoxicity and inhibit fibril formation. Molecular Immunology, 2009. 46(4): p.695-704.

82. Wacker, J., et al., Oligomer-targeting with a conformational antibody fragment promotes toxicity in A beta-expressing flies. Acta Neuropathologica Communications, 2014. 2.

83. Nabuurs, R.J.A., et al., In Vivo Detection of Amyloid-beta Deposits Using Heavy Chain Antibody Fragments in a Transgenic Mouse Model for Alzheimer's Disease. Plos One, 2012. 7(6).

84. Messer, A. and S.N. Joshi, Intrabodies as Neuroprotective Therapeutics. Neurotherapeutics, 2013. 10(3): p. 447-458.

85. Vuchelen, A., et al., H-1, C-13 and $\mathrm{N}-15$ assignments of a camelid nanobody directed against human alpha-synuclein. Biomolecular Nmr Assignments, 2009. 3(2): p. 231-233.

86. De Genst, E.J., et al., Structure and Properties of a Complex of alpha-Synuclein and a SingleDomain Camelid Antibody. Journal of Molecular Biology, 2010. 402(2): p. 326-343.

87. Guilliams, T., et al., Nanobodies Raised against Monomeric alpha-Synuclein Distinguish between Fibrils at Different Maturation Stages. Journal of Molecular Biology, 2013. 425(14): p. 2397-2411.

88. Miller, T.W. and A. Messer, Intrabody applications in neurological disorders: Progress and future prospects. Molecular Therapy, 2005. 12(3): p. 394-401.

89. Schut, M.H., et al., Selection and characterization of llama single domain antibodies against $\mathrm{N}$-terminal huntingtin. Neurological Sciences, 2015. 36(3): p. 429-434.

90. Verheesen, P., et al., Prevention of oculopharyngeal muscular dystrophy-associated aggregation of nuclear poly(A)-binding protein with an intracellularly expressed camelid-derived antibody domain. Neuromuscular Disorders, 2006. 16(9-10): p. 710-711. 
